Financial Markets, Institutions and Risks, Volume 4, Issue 1, 2020

ISSN (online) - 2521-1242 ISSN (print) - 2521-1250

\title{
Banking strategic management and business model: bibliometric analysis ${ }^{4}$
}

http://doi.org/10.21272/fmir.4(1).76-85.2020

\section{Yana Kryvych}

$\mathrm{PhD}$, Associate Professor, Sumy State University, Ukraine

\section{Tetiana Goncharenko}

$\mathrm{PhD}$, Associate Professor, Sumy college of economic and trade, Ukraine

\begin{abstract}
The article is devoted to the analysis of tendencies and research of approaches to definition of strategic management of the bank in the scientific literature, to the identification of future perspective directions of research of this problem. VOSviewer software was used for bibliometric analysis, the object of the study was 5901 articles in scientific journals indexed by Scopus and Web of Science scientific databases, the study period was the time interval from 1991 to 2019. The article substantiates that in 2007-2009 the focus of the study has shifted from general strategic management issues to risk management issues of the bank's business strategy. In 2019, the number of papers devoted to strategic bank management increased rapidly - by $343 \%$ compared to 2007. The use of the VOSviewer tool revealed 5 clusters of the relationship between strategic bank management theory and other theories based on scientific concepts. The largest research cluster combines the expertise of researchers who study strategic bank management in close connection with concepts that study the bank's business models, business strategy, competition, banking performance, banking services and more. The second largest cluster brought together scholars who study the theory of strategic bank management at the intersection with the theories of strategic planning, finance, commerce, e-commerce, management, information management, planning, investing, technological development and more. The third largest cluster brings together scholars who consider strategic bank management through the lens of corporate governance, corporate strategy, financial market trends, retail banking, bank profitability, and more. The conducted research leads to the conclusion that business strategy, profitability and strategic risk management are the priority components of banking strategic management.
\end{abstract}

Keywords: bank, banking, strategy, strategic management, business strategy, business model.

JEL Classification: G21.

This work is licensed under a Creative Commons Attribution 4.0 International License

Cite as: Kryvych, Y., Goncharenko, T. (2020). Banking strategic management and business model: bibliometric analysis. Financial Markets, Institutions and Risks, 4(1), 76-85. http://doi.org/10.21272/fmir.4(1).76-85.2020.

(C) The Authors, 2020. This article is published with open access at Sumy State University.

\section{Introduction}

The ongoing tendency on extending the banking regulation, the appearance of fintech innovation lead to a reorientation of the business activities banks, disappearance one's business models and appearance others. The strategic management terminology in the banking industry started to be used more frequently in the last decade after the World financial crisis 2007-2009, both by academics and banking professionals. In this paper, we performed a literature review regarding the use and the connections of strategic management terminology in the banking industry. First, the study aims to summarize the level of knowledge strategic management terminology in the banking industry. A second aim is to correlate published material regarding banking strategy to answer the question regarding the that terminology have strong connections with banking strategic management. Thus, at the first stage, the definition, principals and features of banking strategic management should be defined. Noted, that traditionally banking strategic management analysed with business strategy and market strategy (financial). However, the huge range of scientists in the papers (Osterwalder (2004))

\footnotetext{
4 The research was funded by the grant from the Ministry of Education and Science of Ukraine (Nos. 0120U100473 "Formation of a toolkit for the unshadowing of the Ukraine economy on the basis of causal modelling of the financial intermediary's interaction trajectories ").
} 
analysed of banking strategic management as a synonym of banking business model which influences on risk taken, profitability and soundness of banks. We used selective criteria like articles published in Clarivates, ScienceDirect, Scopus or Web of Sciences. Finally, the article proposes that as a future study we ought to analyze the link between strategy and business models on a sample of financial institutions.

\section{Literature review}

The widespread use of banking strategic management terminology in academic literature is linked recently with the requirement of financial and bank regulator and development of technology companies.

The scientists in the paper (Osterwalder (2004) associate's strategy, business models and process model (indeed on different business layers), considering that the words are addressing a similar problem. At the same time, in the papers (Magretta, 2002) asserts that strategy is not business model, making a clear distinction between the two terms. Recently, Wirtz et al. (2016) opinions are that the term strategic management needs additional researches, especially regarding the link between strategy concept and other consecrated concepts in business management, including business model.

Banking history suggests that banks suffered enormous losses due to lack of proper strategic management. Beltratti and Stulz (2009) observed poor and flexible management, and very low risk appetite which caused banks serious liquidity and financial issues.

The strategic management itself emphasizes on the change (internal and external) adaptation, but in real world, it is challenging to adapt changes according to prevailing markets (Agarwal et al., 2009). Therefore, banks need to restructure and reorganize their managerial structure under the light of new regulations. Regulatory authorities alone are not enough to implement the strategic rules but in need of concurrent banking cooperation.

The results of the analysis showed that range of scientists (Sanjeepan, N. (2017)) have been consisted on the basis of an ample interpretation of banking sector strategic planning that, along with the instruments and techniques from which it stems, constitutes the essential condition to operate in competitive markets. The concept of planning is examined in its stages, its importance and the benefits for the banking sector in implementing scheduling. The strategic plan model proposed here for the banking sector is examined in detail through the steps towards implementing a plan leading to business improvement. The authors in the paper (Alani et al., 2018) analyzing the linking between strategic orientation and product innovation identified that knowledge management was the core elements of strategic management. Using direct evaluations, the scientists in the papers (Demidova et al., 2019; Sokolenko et al., 2017) analyze heterogeneity among the various business strategies that incorporate systemically important banks. They identify true banking strategies in a portfolio context, that is, consisting of various combinations of bank assets and funding sources. Next, they estimate the way distinct strategies have affected bank profitability and risk before the crisis, as well as their impact on the mortgage crisis. Famous expert of World bank (Demirgüç-Kunt, A., Huizinga, H., 2010) examines the implications of bank activity and short-term funding strategies for bank risk and return.

The scientists (Björk, 2015; Lautenschläger, 2017; Finnegan, 2016; Barnes, 2015; Ogden, 2017; Accenture, 2015 ) analysing the indicator of banking industry during it going through digital changes. It is cheaper to keep loyal customers than to acquire new ones (Björk, 2015). Customer migrated to digital channels. Mobile channels are far more likely to delight and less likely to annoy than the branch or call centre experiences. It is leading to increase loyalty with higher customer retention, repeat purchases and referrals. Customers increasingly expect to follow up with bank staff through digital chat, video or other real-time options and banks actively develop them (Bain \& Company). Representatives of international financial institutions (Lautenschläger, 2017) considers that FinTech will change banks and could be three scenario: banks might team up with FinTech, FinTech might break up the value chain of banking and FinTech could be swallowed up by big Tech companies and deeply transform the banking business. Digital challengers and FinTech giants present a threat for banks and will not go away soon, but at the same time, a wave of innovation in the financial sector offers a number of opportunities for banks, who able to move quickly (Finnegan, 2016). The banks will gain from many new innovations. Square, for instance, is a system that makes it easier for small businesses to take card payments; it will boost banks' transaction volumes. The FinTech revolution will reshape finance and improve it (Financial services, 2015). New banks are operating digital-only models and giving to their customers a full range of banking services in smartphone (Barnes, 2015). App in smartphone can offer advice on wealth building, spending habits and money saving tips. (Ogden, 2017). Customers move at different speeds and make different decisions, every customer is a digital customer now-someone more and someone 
less, from the traditional customer to the digital-savvy one. (Accenture, 2015). The findings proved, that despite of huge range investigations of bank, their risk, profitability, market strategies, business strategies and models from different points of views the banking strategic management issues had not analysed yet considering different aspects of bank activities, digitalisation, fintech innovation etc. In this case, the aim of the paper was analysed of the tendency in the scientific literature on banking strategic management to identify future research directions.

\section{Methodology}

The main hypothesis of investigation is cheeking the increasing tendency on analysing of banking strategic management issues by the scientists. For this purpose, the investigation was done in the following scheme:

$>$ Identifying the quantity tendency of the papers which focused on the analyses of banking strategic management issues.

$>$ Allocating the main subject areas under analyses of banking strategic management issues.

$>$ Identifying the most citation papers and Journals which contained the papers on banking strategic management.

$>$ Clustering the papers on the main directions for investigations with the purpose to identify the further options for analyses.

For the analysis, the following keywords were chosen: bank, banking, banking sector, banking industry, strategy, strategic management. This study reviewed 5901 papers from Scopus and Web of Science. The time for analysis were 1990-2019. The analyse was done by using the software of VOSviewe, WoS analyse and Scopus analyse. Thus, VOSviewer allows to allocate and visualize the network of definitions which used and co-citation during the investigation of banking strategic management. Scopus and WoS tools allowed to analyse the publication towards different parameters: affiliation, journal, citation, number of the papers, funding, the subject area and citations. Thus, in the network visualization of VOSviewer allow to allocate and visualize the scientific direction which has strong relationships. The closer keywords are located to each other, the stronger their relations.

\section{Results}

The findings of analysing proved that in 1997 the numbers of paper which focused on banking strategic management or banking strategy issues began to increase. In addition, during the 2008-2009 and beyond 2012, there has been a significant increase in research on bank strategy and strategic banking management. This may be justified by the widespread problems associated with the global financial crisis (2007-2009) and the need to change the banking paradigm in relation to fintech innovations, the emergence of cryptocurrencies, changes in the regulatory environment, and so on. In 2019 the number of papers which analysed bank strategic management was increased by $343 \%$ compared with the 2007 year (figure 1).

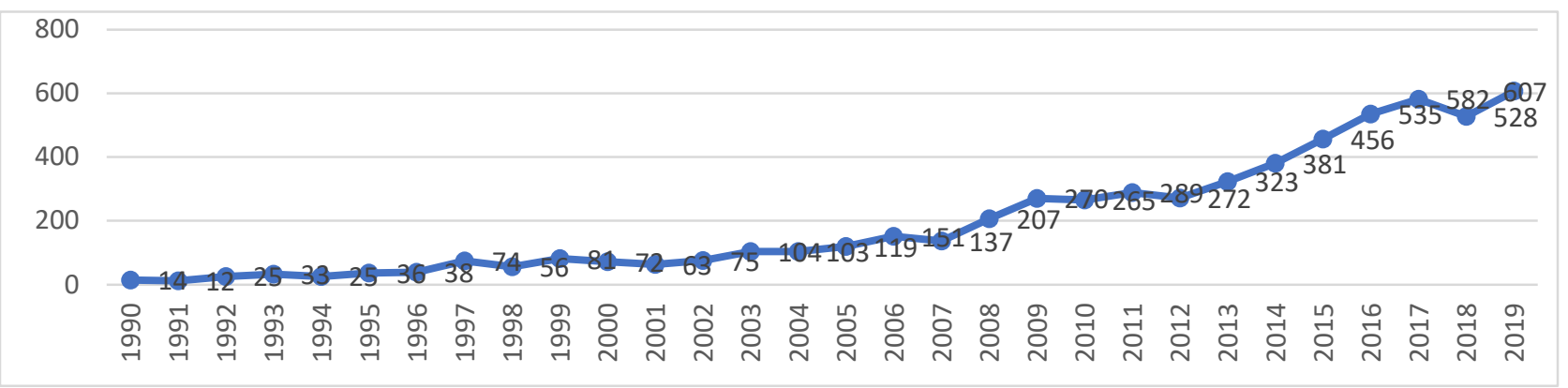

Figure 1. The number of documents in Scopus and WoS which contain the banking strategic management issues

Sources: compiled by the authors using data from Scopus and WoS.

The findings proved that the banking strategic management was analysed according to data of Scopus in the framework of the subject area as follows: Business and Management- $44.63 \%$; Economics, Econometrics and Finance $-31.37 \%$; Social Sciences - 18.36\%; and others (Decision Sciences, Agricultural and Biological Sciences etc.) $-5.64 \%$. 


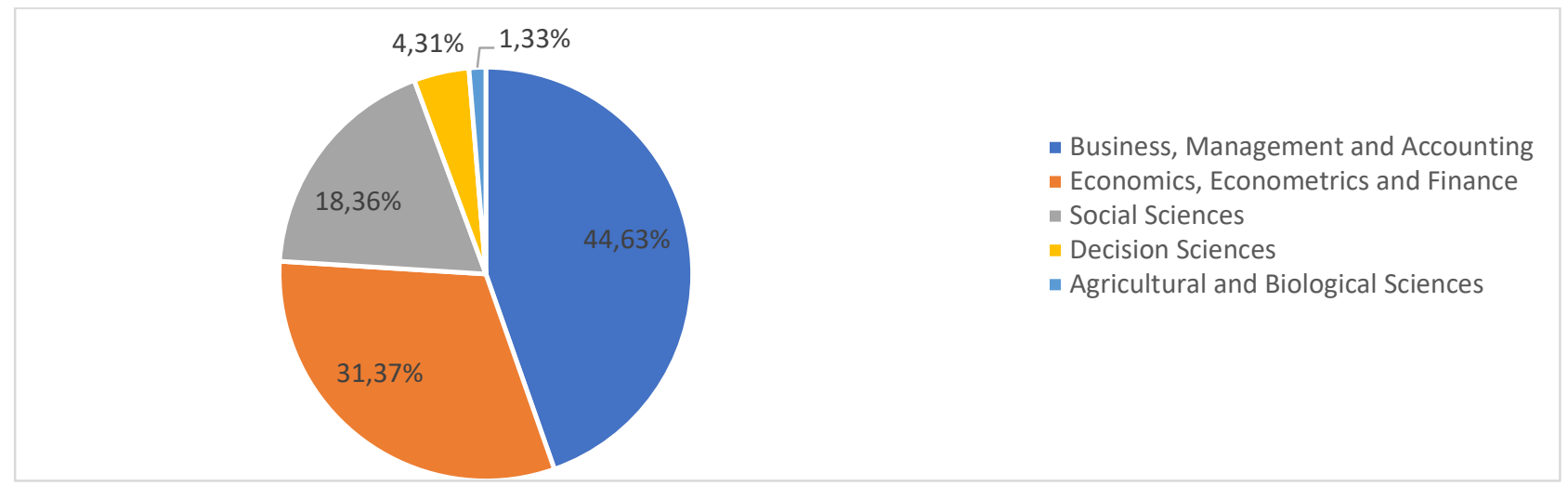

Figure 2. The subject area in Scopus for analysing the banking strategic management issues

Sources: compiled by the authors using data from Scopus.

According to data of WoS in the framework of the subject area the banking strategic management was analysed as follows: Economics- 24.57\%; Management - 20.11\%; Business - 19.11\%; Business finance $16.68 \%$; and others (Social science, Development study etc.) $-19.52 \%$.

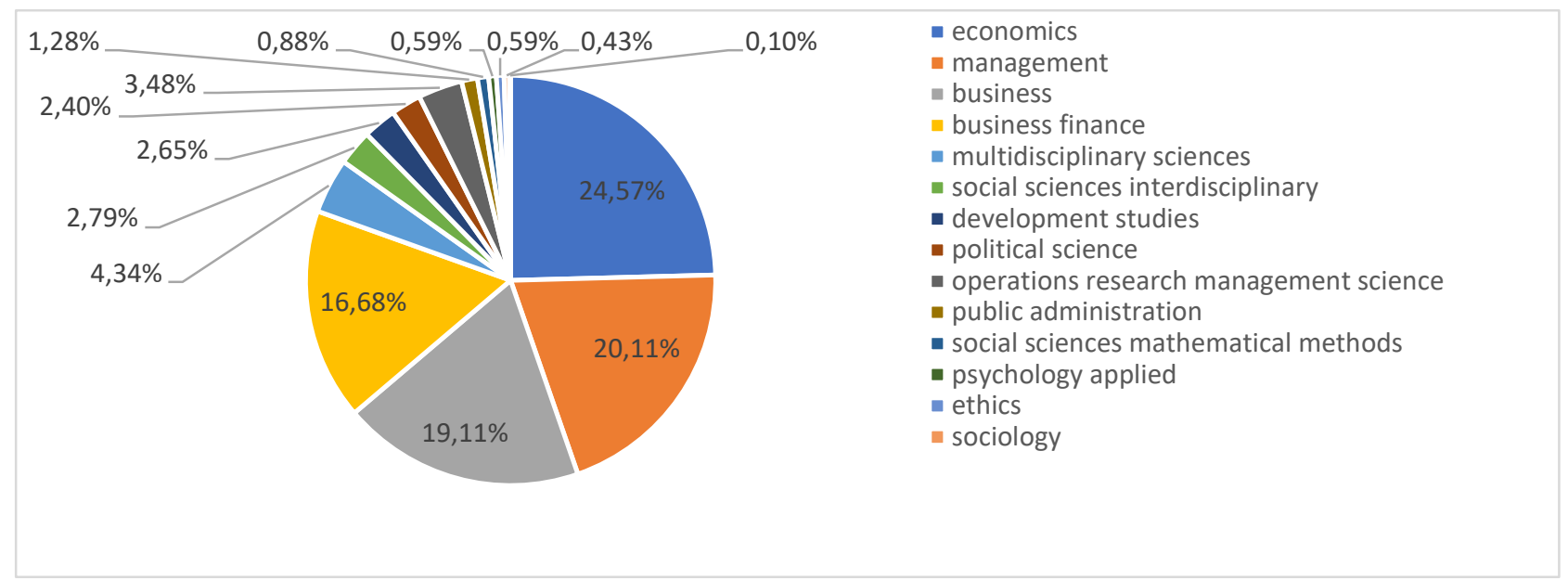

Figure 3. The subject area in WoS for analysing the banking strategic management issues

Sources: compiled by the authors using data from WoS.

The analysis by country showed that mostly the scientist with the USA, Great Britain and China affiliations investigated the banking strategic management issues. The top 20 countries' affiliation of the scientists which investigated the banking strategic management issues according to WoS database showed in Figure 4. Figure 4 also shows the number of publications from these countries in the Scopus database.

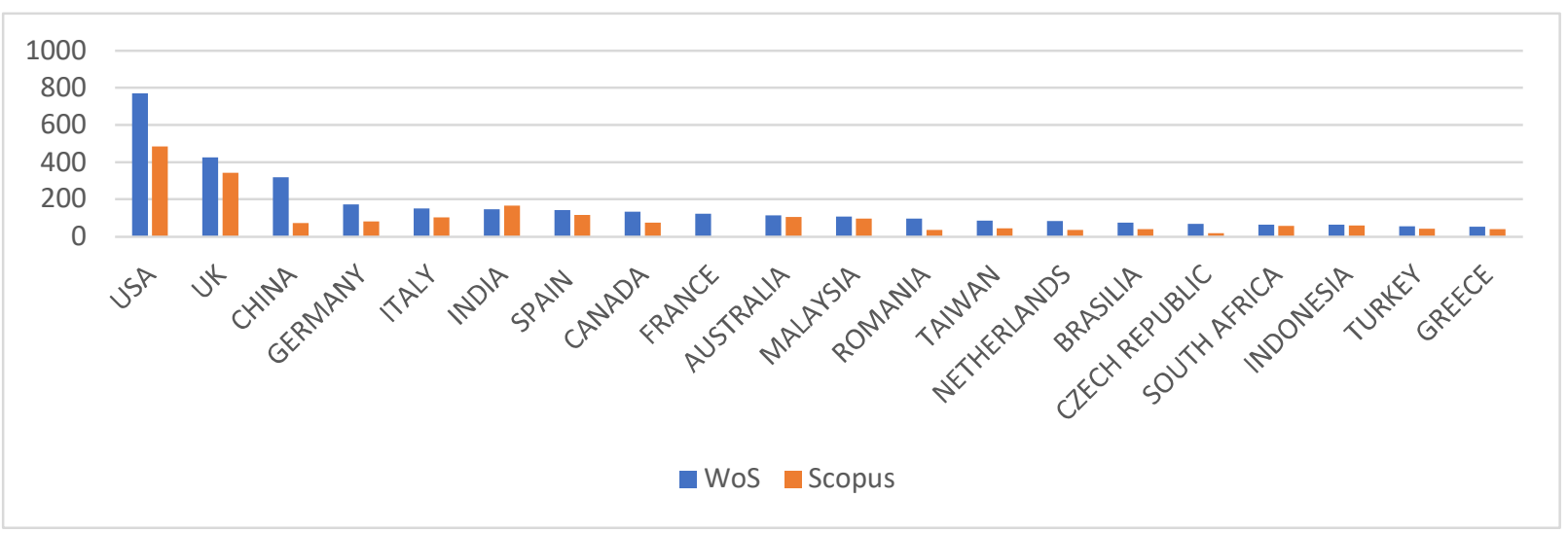

Figure 4. Top 20 country's affiliation of the scientists which investigated the banking strategic management issues

Sources: compiled by the authors using data from WoS and Scopus 
Besides, considering the findings from Scopus in 2018 the high ranked International Journal of Bank Marketing, Czech Journal of Economics and Finance, Journal of Applied Economic Sciences began to publish more papers on green intellectual capital issues (Table 1).

Table 1. The top 5 Journal which published the papers on banking strategic management

\begin{tabular}{|l|c|c|c|c|c|}
\hline \multicolumn{1}{|c|}{ Title of the Journal } & $\begin{array}{c}\text { Covered by } \\
\text { Scopus }\end{array}$ & $\begin{array}{c}\text { CiteScore } \\
2018\end{array}$ & $\begin{array}{c}\text { SJR } \\
2018\end{array}$ & $\begin{array}{c}\text { SNIP } \\
2018\end{array}$ & $\begin{array}{c}\text { Numbers of the } \\
\text { papers }\end{array}$ \\
\hline International Journal of Bank Marketing & 1983 to 2019 & 3.31 & 0.76 & 1.468 & 163 \\
\hline Banks and Bank Systems & 2006 to 2019 & 0.42 & 0.210 & 0.514 & 38 \\
\hline Service Industries Journal & 1983 to 2019 & 2.36 & 0.563 & 0.809 & 33 \\
\hline Journal of Banking and Finance & 1977 to 2019 & 3.08 & 1.599 & 1.857 & 31 \\
\hline Long Range Planning & 1968 to 2019 & 4.42 & 2.036 & 1.839 & 23 \\
\hline
\end{tabular}

Sources: compiled by the authors using data from Scopus.

According to Scopus database 9 from 10 the most cited papers were published by the high ranked Journals. The most cited papers were published by the scientists Anderson E.W., Fornell C., Rust R.T. in 1997 in Marketing Science. In 2010 famous scientists and expert of World bank Demirgüç-Kunt A., Huizinga H. published the paper "Bank activity and funding strategies: The impact on risk and returns" which cited 341 and examined the implications of bank activity and short-term funding strategies for bank risk and return, and proved that banking strategies that rely prominently on generating noninterest income or attracting nondeposit funding are very risky.

Table 2. The most cited papers on banking strategic management 1991-2019 according to Scopus database

\begin{tabular}{|c|c|c|c|}
\hline Authors and Title & Year & Source title & Cited \\
\hline $\begin{array}{l}\text { Anderson, E.W., Fornell, C., Rust, R.T. Customer satisfaction, productivity, } \\
\text { and profitability: Differences between goods and services }\end{array}$ & 1997 & Marketing Science & 653 \\
\hline $\begin{array}{l}\text { Richard, O.C. Racial diversity, business strategy, and firm performance: A } \\
\text { resource-based view }\end{array}$ & 2000 & Academy of Management Journal & 581 \\
\hline $\begin{array}{l}\text { Zollo, M., Singh, H. Deliberate learning in corporate acquisitions: Post- } \\
\text { acquisition strategies and integration capability in U.S. bank mergers }\end{array}$ & 2004 & Strategic Management Journal & 487 \\
\hline $\begin{array}{l}\text { Sathye, M. Adoption of Internet banking by Australian consumers: an } \\
\text { empirical investigation }\end{array}$ & 1999 & $\begin{array}{l}\text { International Journal of Bank } \\
\text { Marketing }\end{array}$ & 464 \\
\hline $\begin{array}{l}\text { Demirgüç-Kunt, A., Huizinga, H. Bank activity and funding strategies: The } \\
\text { impact on risk and returns }\end{array}$ & 2010 & Journal of Financial Economics & 341 \\
\hline $\begin{array}{l}\text { Corsetti, G., Pesenti, P., Roubini, N. What caused the Asian currency and } \\
\text { financial crisis? }\end{array}$ & 1999 & Japan and the World Economy & 329 \\
\hline $\begin{array}{l}\text { Robertson, M.M. The neoliberalization of ecosystem services: Wetland } \\
\text { mitigation banking and problems in environmental governance }\end{array}$ & 2004 & Geoforum & 323 \\
\hline $\begin{array}{l}\text { Laforet, S., Li, X. Consumers' attitudes towards online and mobile banking } \\
\text { in China }\end{array}$ & 2005 & $\begin{array}{c}\text { International Journal of Bank } \\
\text { Marketing } \\
\end{array}$ & 308 \\
\hline $\begin{array}{l}\text { Kuester, K., Mittnik, S.,Paolella, M.S. Value-at-risk prediction: A } \\
\text { comparison of alternative strategies }\end{array}$ & 2006 & Journal of Financial Econometrics & 265 \\
\hline $\begin{array}{l}\text { Kamakura, W.A., Mittal, V.,De Rosa, F., Mazzon, J.A. Assessing the } \\
\text { service-profit chain }\end{array}$ & 2002 & Marketing Science & 258 \\
\hline
\end{tabular}

Sources: compiled by the authors using data from Scopus.

Same situation of publishing according to WoS database - 9 from 10 the most cited papers were published by the high ranked Journals. In 2000 famous expert of International money found La Porta, R.; Lopez-De-Silanes, F.; Shleifer, A. published the paper "Investor protection and corporate governance" which cited 1944, and it is the most cited papers in the banking strategic management issues.

Table 3. The most cited papers on banking strategic management 1991-2019 according to WoS database

\begin{tabular}{|l|c|c|}
\hline \multicolumn{1}{|c|}{ Authors and Title } & Year & Source title \\
\hline $\begin{array}{l}\text { La Porta, R.; Lopez-De-Silanes, F.; Shleifer, A.; et al. Investor protection } \\
\text { and corporate governance }\end{array}$ & 2000 & Journal of Financial Economics \\
\hline $\begin{array}{l}\text { Wenger, E.C.;Snyder, W.M. Communities of practice: The organizational } \\
\text { frontier }\end{array}$ & 2000 & Harvard Business Review \\
\hline $\begin{array}{l}\text { Han, J.K.; Kim, N.; Srivastava, R.K. Market orientation and organizational } \\
\text { performance: Is innovation a missing link? }\end{array}$ & 1998 & Journal of Marketing \\
\hline Klein, K.J.; Sorra, J.S. The challenge of innovation implementation & 1996 & Academy of Management Review \\
\hline $\begin{array}{l}\text { Lee, C.; Lee, K.; Pennings, J.M. Internal capabilities, external networks, and } \\
\text { performance: A study on technology-based ventures }\end{array}$ & 2001 & Strategic Management Journal \\
\hline
\end{tabular}


Table 3 (cont.). The most cited papers on banking strategic management 1991-2019 according to WoS database

\begin{tabular}{|l|c|c|}
\hline $\begin{array}{l}\text { Johnson, R.A.; Greening, D.W. The effects of corporate governance and } \\
\text { institutional ownership types on corporate social performance }\end{array}$ & 1999 Academy of Management Journal \\
\hline $\begin{array}{l}\text { Khanna, T.; Rivkin, J.W. Estimating the performance effects of business } \\
\text { groups in emerging markets }\end{array}$ & 2001 & Strategic Management Journal \\
\hline Deephouse, D.L. Does isomorphism legitimate? & 1996 & Academy of Management Journal \\
\hline $\begin{array}{l}\text { Hallowell, R. The relationships of customer satisfaction, customer loyalty, } \\
\text { and profitability: An empirical study }\end{array}$ & 1996 & $\begin{array}{c}\text { International Journal OF Service } \\
\text { Industry Management }\end{array}$ \\
\hline $\begin{array}{l}\text { Black, B.S.; Gilson, R.J. Venture capital and the structure of capital markets: } \\
\text { banks versus stock markets }\end{array}$ & 1998 & Journal of Financial Economics \\
\hline
\end{tabular}

Sources: compiled by the authors.

The findings from VOSviewer identified 5 clusters of the papers which investigated banking strategic management from the different points of views (Figure 5) (See in Appendix).

The first biggest cluster (red cluster) merged the paper which contained the keywords as follows: banking sector(s), business model, business strategy, competition, performance, sale, strategy etc. The second biggest cluster (green cluster) contained such issues as follows: strategic planning, finance, commerce, electronic commerce, management, information management, planning, investment, technology etc. The third biggest cluster (blue cluster) focused on: banking, corporate governance, corporate strategy, financial institution, financial market, fintech, retail banking, strategic approach, profitability, strategic management etc. Next two small clusters yellow (risk management) and purple (customer satisfaction).

Noted, that three clusters yellow (risk management), red (sales) and green (strategic planning) located close to each other. The closer location of the abovementioned cluster to each other proved the stronger their relations. Such tendency allows making a conclusion, that banking risk management and market position is a part of strategic management and planning and very closely connected with business model, performance and profitability. At the same time, the findings proved that technology, fintech, information management become important part of banking strategic management and is becoming increasingly popular in research and investigating by the huge range of the authors. At the same time, banking strategic management which involved banking business model is new directions of investigation. Thus, considering the findings from Figure 6 the strategic management relates to financial market, profitability and risk management.

Thus, at the next stage, with the purpose to do a deep analysis of the co-citations on banking strategic management the second biggest cluster from Figures 6 (See in Appendix) were analysed in detail. The keywords were chosen as follows: sales, business strategy, competition, competitive advantage, customer relationship management and performance. The findings showed in Figure 6 (See in Appendix). Considering the results, 5 clusters. The biggest was red, green and blue. In this case, the blue cluster contained keywords as follows: banking, corporate governance, corporate strategy, financial institution, financial market, finteh, retail banking, strategic approach, profitability. Thus, the findings proved the research hypothesis that from 2007-2009 (World financial crises) the quantity of the papers which analysed the banking strategic management issues are increasing. At the same time, the most related areas with banking strategic management were sales, business strategy, competition, competitive advantage, performance, profitability and risk management.

\section{Conclusion}

The results of the analysis proved that banking strategic management is a popular direction for investigation which formed in separate scientific school. Besides, the quantity of paper become increased from the 20072009 years (World financial crises). The findings from VOSviewer allow allocating 5 clusters. Three among them have a close relationship. The first biggest cluster merged the keywords as follows: business model, business strategy, competition, performance, sale, strategy etc. The second biggest cluster merged the keywords as follows: strategic planning, finance, commerce, electronic commerce, management, information management, planning, investment, technology etc. The third biggest cluster focused on: corporate governance, corporate strategy, financial institution, financial market, fintech, retail banking, strategic approach, profitability etc. Such tendency allows making a conclusion, that technology, fintech, information management become important part of banking strategic management.

\section{Funding}

This research was funded by the grant from the Ministry of Education and Science of Ukraine (Nos. $\mathrm{g} / \mathrm{r}$ 0118U003574). The research was funded by the grant from the Ministry of Education and Science of Ukraine 
ISSN (online) - 2521-1242 ISSN (print) - 2521-1250

(Nos. 0120U100473 "Formation of a toolkit for the unshadowing of the Ukraine economy on the basis of causal modelling of the financial intermediary's interaction trajectories ").

\section{References}

1. Accenture. (2015). Banking Customer 2020. Rising Expectations Point to the Everyday Bank. [Online] Available at: https://www.accenture.com/t20150710T130243 w /us-en/ acnmedia/Accenture/ Conversion-Assets/DotCom/Documents/Global/PDF/Dualpub 17/Accenture-Banking-Consumer-Pulse.pdf 2. Alani, E., Kamarudin, S., Alrubaiee, L., \& Tavakoli, R. (2019). A model of the relationship between strategic orientation and product innovation under the mediating effect of customer knowledge management. Journal of International Studies, 12(3), 232-242. doi:10.14254/2071-8330.2019/12-3/19

3. Agarwal, Sumit, John C. Driscoll, Xavier Gabaix, and David Laibson. (2009). The age of reason: financial decisions over the life-cycle with implications for regulation. Brookings Papers on Economic Activity 2:51-117.

4. Bain \& Company. (2015). Customer Behaviour, Experience and Loyalty in Retail Banking. [Online] Available at:http://www.bain.com/publications/articles/customer-loyalty-in-retail-banking-2015-global.aspx. 5. Beltratti, Andrea and Stulz, Rene M. (July 13, 2009). Why Did Some Banks Perform Better during the Credit Crisis? A Cross-Country Study of the Impact of Governance and Regulation. Fisher College of Business Working Paper No. 2009-03-012. Available at: https://papers.ssrn.com/sol3/papers. $\underline{\text { cfm? abstract id }=1433502}$

6. Björk, S. (2015). Corporate customer loyalty within the banking Sector: The case of SEB. [Online]. Available at: http://www.diva-portal.org/smash/get/diva2:886167/FULLTEXT01.pdf.

7. Demirgüç-Kunt, A., Huizinga, H. (2010). Bank activity and funding strategies: the impact on risk and returns. Journal of Financial Economics 98, 626-650. Available at: https://econpapers.repec.org/article leeejfinec/v_3a98_3ay_3a2010_3ai_3a3_3ap_3a626-650.htm

8. Hryckiewicz, A., Kozlowski, L. (2015). Banking business models and the nature of financial crises. MPRA Paper 64072, University Library of Munich, Germany. Available at: https://ideas.repec.org/p/pra/mprapa/ 64072.html, revised 09 Mar 2015.

9. Financial services. (2015). The fintech revolution. A wave of startups is changing finance- for the better. [Online] Available at: http://www.economist.com/news/leaders/21650546-wave-startups-changingfinancefor-better-fintech-revolution.

10. Lautenschläger, S. (2017). Digital native? Fintechs and the future of banking. [Online] Available at: https://www.bankingsupervision.europa.eu/press/speeches/date/2017/ html/se170327 1.en.html

Ogden, J. (2017). The Biggest Challenge Facing Banks in 2017 and a Checklist to Overcome It. [Online] Available at: https://www.mx.com/moneysummit/the-top-5-consumer-wants-in-banking-and-a-checklist-tomeet-them.

11. Osterwalder, A. (2004). The Business Model Ontology-A Proposition in a Design Science Approach. PhD Thesis, University of Lausanne, Switzerland. Available at: http://www.hec.unil.ch/aosterwa/ PhD/Osterwalder_PhD_BM_Ontology.pdf

12. Sanjeepan, N. (2017). Strategic Analysis and Strategic Planning for Commercial Banking (An Analysis based a Commercial Bank operating in Sri Lanka). Int J Econ Manag Sci 6: 418. Available at: https://www.hilarispublisher.com/open-access/strategic-analysis-and-strategic-planning-for-commercialbanking-an-analysis-based-a-commercial-bank-operating-in-sri-lanka-2162-6359-1000418.pdf 


\section{Appendix}

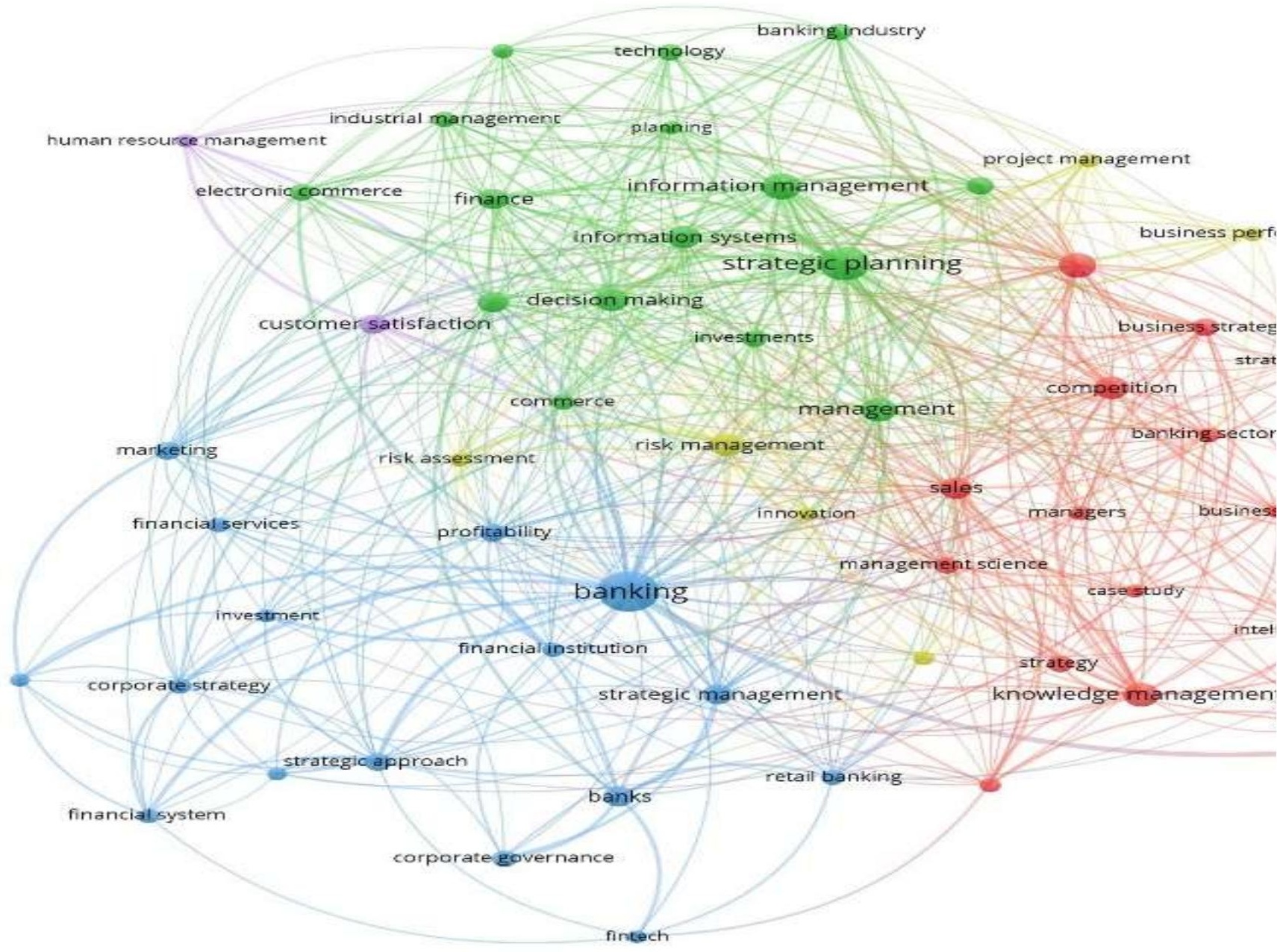

Figure 5. The network visualization of the co-citation of the papers on banking strategic manage

Sources: compiled by the authors using the Scopus and WoS database and VOSviewer tool. 


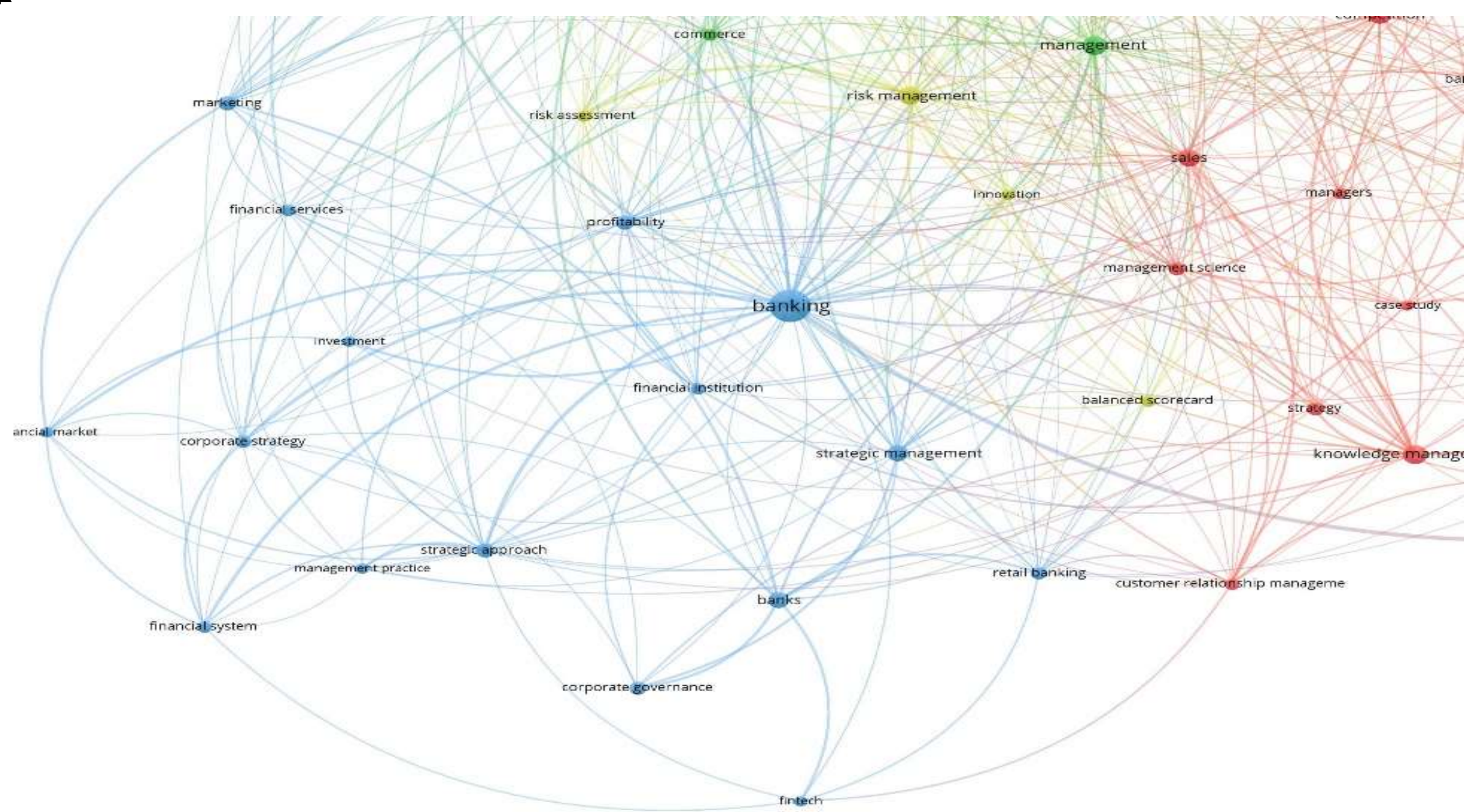




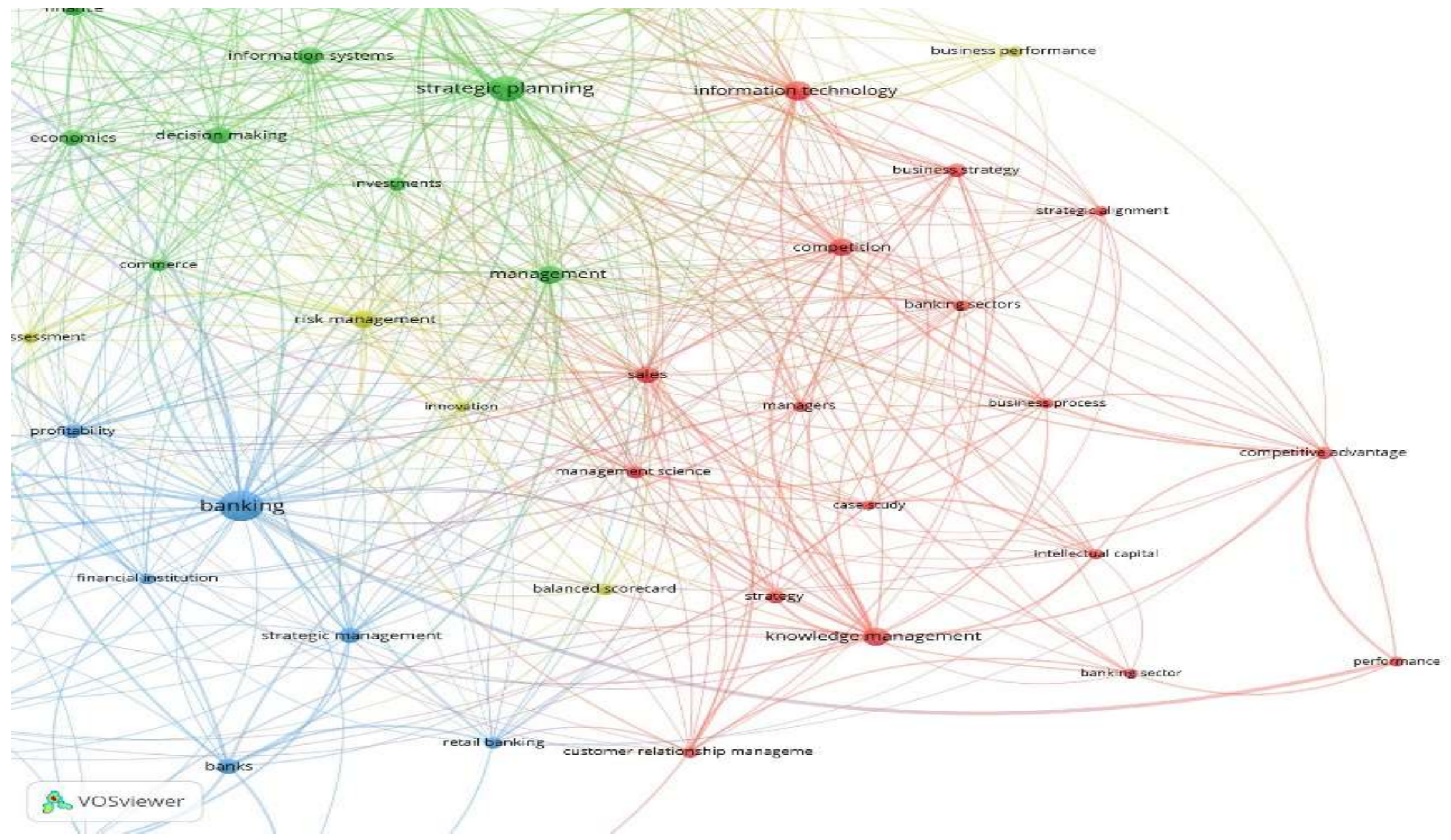

Figure 7. The network visualization of the co-citation of the keywords on green intellectual capital, green capital, green assets, green innovations and development.

Sources: compiled by the authors using the Scopus and WoS database and VOSviewer tool. 